\title{
CONTROL OF GUMMY STEM BLIGHT IN WATERMELON THROUGH DIFFERENT MANAGEMENT SYSTEMS
}

\author{
CONTROLE DA PODRIDÃO GOMOSA EM MELANCIA ATRAVÉS DE DIFERENTES \\ SISTEMAS DE MANEJO
}

\section{Gil Rodrigues dos SANTOS ${ }^{1}$; Samilla Candida Rodrigues SOUSA ${ }^{2}$; Fernando Cezar JULIATTI ${ }^{3}$; Artenisa Cerqueira RODRIGUES ${ }^{4}$; Mateus Sunti DALCIN ${ }^{5}$; Aurenivia BONIFÁCIO ${ }^{6}$}

1. EngenheiroAgrônomo, Professor, Doutor, Departamento de Fitopatologia, Universidade Federal do Tocantins - UFT, Gurupi, TO, Brasil. gilrsan@uft.edu.br; 2. Engenheira Agrônoma, Mestre, Laboratório de Micologia e Proteção de Plantas - LAMIP, Instituto de Ciências Agrárias - ICIAG, Universidade Federal de Uberlândia - UFU, Uberlândia, MG, Brasil; 3. Engenheiro Agrônomo, Professor, Doutor, LAMIP - ICIAG - UFU, Uberlândia, MG, Brasil. juliatti@ufu.br; 4. Engenheira Agrônoma, Professora, Doutora em Agronomia, Departamento de Engenharia Agrícola e Solos, Universidade Federal do Piauí, Teresina, Brasil; 5. Engenheiro Agrônomo, Mestre em Produção Vegetal, Aluno de doutorado do Programa de Pós-Graduação em Produção Vegetal da UFT, Gurupi, TO, Brasil; 6. Bióloga, Professora, Doutora em Bioquímica, Departamento de Biologia, Universidade Federal do Piauí, Teresina, Brasil.

\begin{abstract}
Gummy stem blight, caused by Didymella bryoniae (Auersw.) Rehn, is a disease that affects the productivity of watermelon leading to losses exceeding $40 \%$. This study aimed at evaluating the efficiency of different production systems in the control of watermelon gummy stem blight in order to establish effective methods to combat the disease. The following treatments were applied: conventional management, integrated management and organic production. Mineral fertilizer was applied to conventional and integrated management, whereas in organic production was used the cattle manure. There was application of fungicides and insecticides in commercial doses in conventional and integrated management, and the application was according to monitoring in integrated management. No fungicide or insecticide was applied to organic production. The disease severity was assessed by rating scale. The experimental design was randomized blocks. The severity of gummy stem blight increased substantially during fruit formation. Watermelon plants grown with integrated management showed lower levels of disease severity, while plants in organic production exhibited higher severity levels. We conclude that the management based on judicious monitoring in field is the best way to attain appropriate phytosanitary quality for the watermelon crop in Tocantins State, Brazil.
\end{abstract}

KEYWORDS: Didymella bryoniae. Organic production. Citrullus lanatus. Productivity.

Watermelon (Citrullus lanatus (Thunb.) Matsum \& Nakai) is a cucurbit with great socioeconomic importance, especially in North and Northeast Brazil, due to the employment of family labor on small farms (MIRANDA et al., 2005; LEÃO et al., 2008). In Tocantins State, the watermelon is produced mainly in the city of Lagoa da Confusão and generates a yield of 29.2 tons per hectare (IBGE, 2013). The cultivation of watermelon is easy to handle and with lower production costs compared to other vegetable crops. The incidence of diseases is considered one of the limiting factors to the production of watermelon, in view of the huge losses in productivity and fruit quality (SANTOS et al., 2013). Moreover, the incidence of diseases affects fruit appearance leading to its disposal and therefore increased cost of production (MIRANDA et al., 2005; LEÃO et al., 2008).

Gummy stem blight (Didymella bryoniae (Auersw) Rehm) and its anamorph Ascochyta cucumis Fautr. \& Roum is one of the main diseases affecting the watermelon plants. The pathogen cause epidemic in both anamorphic as in teleomorf stages (Kurosawa et al. 2005). The fungus D. bryoniae can remain viable for up to three years in crop residues and weeds (SANTOS et al., 2005). The disease is manifested in the stem, leaves and fruits (SANTOS et al., 2009). In the leaves, one may notice circular patches of dark color, often with a yellow halo and with the disease progression there is aggravation of injuries that become brittle (MORAIS et al., 2008). Although there are sources of incomplete resistance (SANTOS; CAFÉ-FILHO, 2005), and fungicides are partially effective (SANTOS et al., 2005), disease progress is extremely fast, even from localized point-source inoculum (CAFÉ-FILHO et al., 2010). For control of gummy stem blight, the use of cultural practices such as rotation of non-host crops, fertilizer management, proper spacing, genetic and chemical control with the use of tolerant and/or resistant genotypes to disease are recommended (SANTOS et al., 2013).

In Brazil, the inter-row spacing for planting watermelon generally ranges from 2.0 to $3.0 \mathrm{~m}$ and from $0.7 \mathrm{~m}$ to $2.0 \mathrm{~m}$ between-plants in the row, 
leaving two or one plant per hole. The increased spacing results in increased growth and production of watermelon plants (WALTERS, 2009). Miranda et al. (2005) recorded higher number of fruits per plant and greater fruit weight with a $2.0 \times 1.0 \mathrm{~m}$ spacing and one plant per hole. In addition, it is recommended the reasonable use of chemicals, particularly pesticides and fertilizers, in order to increase crop production with practices of integrated management and use of biofertilizers (MORAIS et al., 2008; UCHÔA et al., 2012).

Organic matter in soil is an important factor for growing watermelons and as they might influence the availability of nutrients (MORAIS et al., 2008; SOUZA et al., 2008; UCHÔA et al., 2012). Leão et al. (2008) reported increased productivity of watermelon with the application of increasing levels of cattle manure. There are indications in the literature on rates of cattle manure for the watermelon crop, but the effects of organic fertilizer in the development of diseases in watermelon have not been demonstrated. Thus, this study aimed to evaluating the efficiency of different production systems in the control of watermelon gummy stem blight in order to establish effective methods to combat the disease.

The experiment was conducted in the experimental field of the Federal University of Tocantins (UFT) located in Gurupi/TO $\left(11^{\circ} 43^{\prime} 45^{\prime \prime} \mathrm{S}\right.$ and $\left.49^{\circ} 04^{\prime} 07^{\prime \prime} \mathrm{W}\right)$. The experimental area has $280 \mathrm{~m}$ average altitude, B1wA'a climate (according to Köppen) and soil classified as Dystrophic Yellow Red Latosol (EMBRAPA, 2006). Soil preparation was performed following the conventional system. Five watermelon seeds were sown in holes of $5.0 \mathrm{~cm}$ deep covered with $2.0 \mathrm{~cm}$ of soil and after 15 days after planting (DAP), there was roughing up leaving two plants per hole. Treatments started before sowing at the time of the installation of the experiment and fertilizer application.

The following treatments were applied: conventional management; integrated management; and organic production (Table 1). In conventional management, the spacing was $2.70 \times 1.20 \mathrm{~m}$ with fertilization of $850 \mathrm{~kg} \mathrm{ha}^{-1}$ NPK (05-25-15) and weekly application of fungicides and insecticides at recommended commercial doses. In integrated management, the spacing was $2.0 \times 2.0 \mathrm{~m}$ with fertilization after soil analysis and application of fungicides and insecticides according to monitoring every three days and respecting the damage level defined for each pest after consulting the specific literature. In organic production, the spacing was 2.0 x $2.0 \mathrm{~m}$ with organic fertilizer $(4 \mathrm{~kg}$ of cattle manure per hole) and no application of fungicides/insecticides. In organic production, the insect-pests were eliminated manually.

Table 1. Management systems applied in watermelon cultivation for control of gummy stem blight caused by Didymella bryoniae fungi.

\begin{tabular}{|c|c|c|c|}
\hline $\begin{array}{c}\text { Variables of } \\
\text { management system }\end{array}$ & $\begin{array}{l}\text { Conventional } \\
\text { management }\end{array}$ & $\begin{array}{c}\text { Integrated } \\
\text { management }\end{array}$ & $\begin{array}{c}\text { Organic } \\
\text { production }\end{array}$ \\
\hline Spacing & $2.70 \times 1.20 \mathrm{~m}$ & $2.0 \times 2.0 \mathrm{~m}$ & $2.0 \times 2.0 \mathrm{~m}$ \\
\hline Fertilization & $\begin{array}{c}850 \mathrm{~kg} \mathrm{ha}^{-1} \\
\text { of NPK }(05-25-15)\end{array}$ & $\begin{array}{l}\text { According to } \\
\text { soil analysis }\end{array}$ & $\begin{array}{l}4 \mathrm{~kg} \text { of cattle } \\
\text { manure per hole }\end{array}$ \\
\hline Fungicides & Applied weekly* & $\begin{array}{l}\text { According } \\
\text { to monitoring }\end{array}$ & Not applied \\
\hline Insecticides & Applied weekly ${ }^{\#}$ & $\begin{array}{l}\text { According } \\
\text { to monitoring }\end{array}$ & Not applied ${ }^{\S}$ \\
\hline
\end{tabular}

${ }^{*}$ Fungicides: Methyl tiophanate, metalaxyl-mancozeb, chlorothalonil and copper oxide; ${ }^{\sharp}$ Insecticides: Acephate and deltrametrina; ${ }^{\circledR}$ The insect pests were manually deleted every two days.

The experiment was arranged in a randomized block design with three treatments (conventional management; integrated management; and organic production) and four replications. The experimental plot took up an area of $38.88 \mathrm{~m}^{2}$ for conventional management, whereas for integrated management and organic production the size of the experimental plot was $48 \mathrm{~m}^{2}$. In each experimental plot were included 20 plants, regardless of the treatment. Data were analyzed by ANOVA and means were compared by the Tukey's test at the 0.05 level of confidence. All analyses were performed using the statistical software SISVAR ${ }^{\circledR}$.

The weed control was performed by hand weeding and the crowning of the plants at 25 and 50 DAP. Irrigation was performed daily by hand with 24 liters per hole. The experiment was conducted in two periods: from August to November 2012 (dry period) and between January and March 2013 (wet period). The climatic data of the dry and wet periods 
are shown in Figure 1. The estimated severity in leaves was conducted every five days until fruits harvest. For that, it was utilized a rating scale created by Santos et al. (2005), as follow: 0 - health plant; 1 - less than $1 \%$ of affected leaf area; 3 - between 1 and $5 \%$ of affected leaf area; 5 - between 6 and 25\% diseased leaf area; 7 - between 26-50\% diseased leaf; 9 - more than $50 \%$ of affected leaf area.

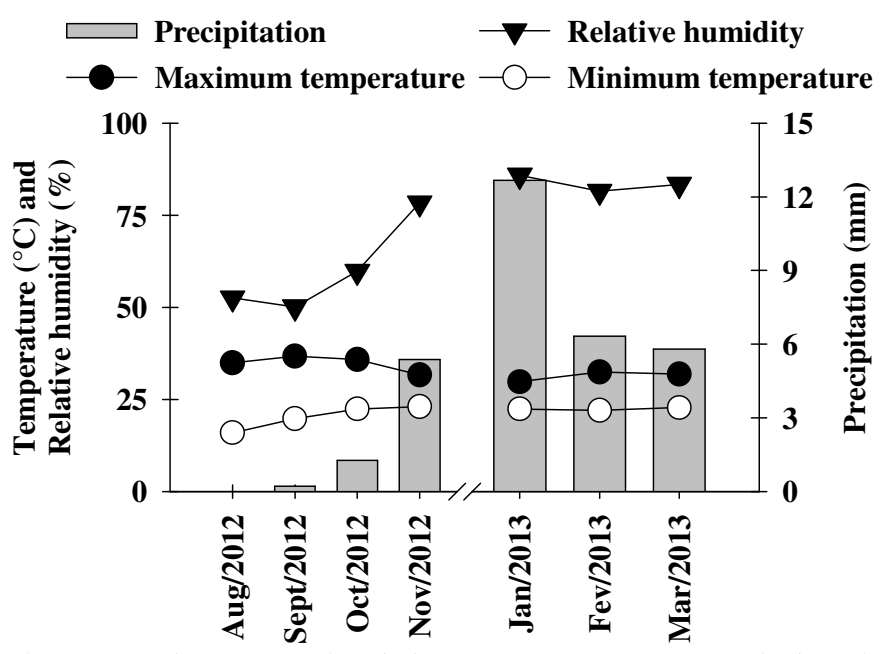

Figure 1. Meteorological data (maximum and minimum temperature; relative humidity; and precipitation) recorded in the experimental area from August to November 2012 (dry period) and between January and March 2013 (wet period).

With data on severity, the area under the disease progress curve (AUDPC) was calculated for the two periods (dry and wet periods) of study according to Shaner and Finney (1977). Considering that in wet period there was no fruit production, measured the fruits weight, the number of rotten fruits and the yield $\left(\mathrm{tha}^{-1}\right)$ only in the dry period. Thus, the total soluble solids ( ${ }^{\circ}$ Brix) were also measured only in dry period. The measurement of ${ }^{\circ}$ Brix was performed using refractometer after steeping and filtering the fruit pulp (IAL, 2008).
The area under the disease progress curve (AUDPC) for gummy stem blight in watermelon plants varied in response to the different managements used and crop seasons (Figure 2). The AUDPC reflects the speed at which the disease manifests over time and higher values indicate more rapid disease progression (SIMKO; PIEPHO, 2012). AUDPC were calculated separately in the dry and wet periods. In the low rainfall period, there was lower AUDPC in the treatment of integrated management, while the other treatments did not differ statistically (Tukey's test; $P<0.05$ ).

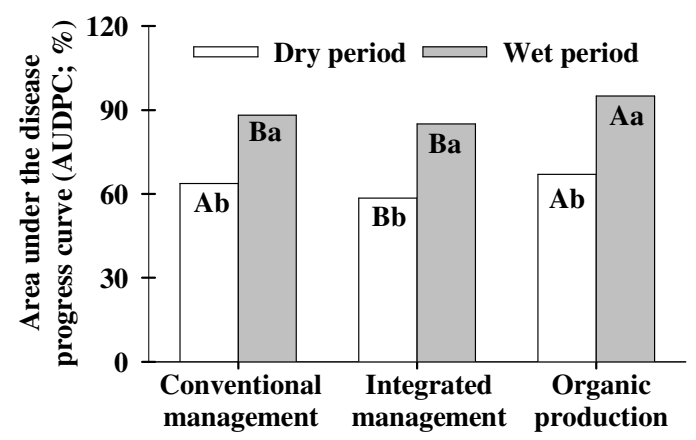

Figure 2. Area under the disease progress curve (AUDPC) calculated based on the severity of the gummy stem blight (Didymella bryoniae) incident in watermelon plants subjected to conventional management, integrated management and organic production from August to November 2012 (dry period) and between January and March 2013 (wet period). Different capital letters represent significant differences between treatments in studied periods, whereas different lower case represent significant differences between periods in the same treatment, both according to Tukey's test $(P<0.05)$. 
There was higher AUDPC in the period of highest rainfall for all three treatments (Figure 2). In this period, the watermelon plants subjected to organic management showed higher AUDPC while the other treatments were statistically equal (Tukey test, $P<0.05)$. The presence of rains, resulting in increased relative humidity, creates an ideal microclimate for emergence of fungal diseases, such as gummy stem blight ( $D$. bryoniae) in watermelon and melon and black-sigatoka (Mycosphaerella fijiensis) in banana microclimate (UCHÔA et al., 2012; SANTOS et al., 2013). Moisture is essential for germination and germ tube penetration of most fungal spores by natural and/or injury of leaves and branches (SANTOS et al., 2013).

Due to the heavy rainfall recorded in the period of January to March 2013 (wet period) and the high severity of gummy stem blight, the fruits produced by watermelon plants showed up rotten and therefore were not computed as yield. A similar result was observed by Santos et al. (2009), which resulted in loss of $100 \%$ fruit production due to an intense attack of gummy stem blight and mildew. Therefore, the evaluation of fruits and yield estimates were performed only in the period low rainfall period from August to November 2012 (dry period). As shown in Figure 3A, there were no significant differences between weights of fruits in different management systems. Although no significant difference was detected, there was a trend towards heavier fruits in plants subjected to integrated management.

Regarding the number of rotten fruits (fruits plant $^{-1}$ ), there was a higher number of rotten plants subjected to conventional management. According to Santos et al. (2013), fruits rot can be caused by $D$. bryoniae and likewise by other fungi belonging to the genres Pythium sp., Rhizoctonia solani and Fusarium sp. The occurrence of these fungi is strongly related to moisture in the soil along with the management system adopted (SANTOS et al., 2009). Temperature and humidity are the environmental factors that strongly affect the onset and progress of infectious diseases in plants (UCHÔA et al., 2012). Moreover, the spread and increase the progress rate of gummy stem blight caused by the pathogen $D$. bryoniae can be directly related to water splash (CAFÉ-FILHO et al., 2010).
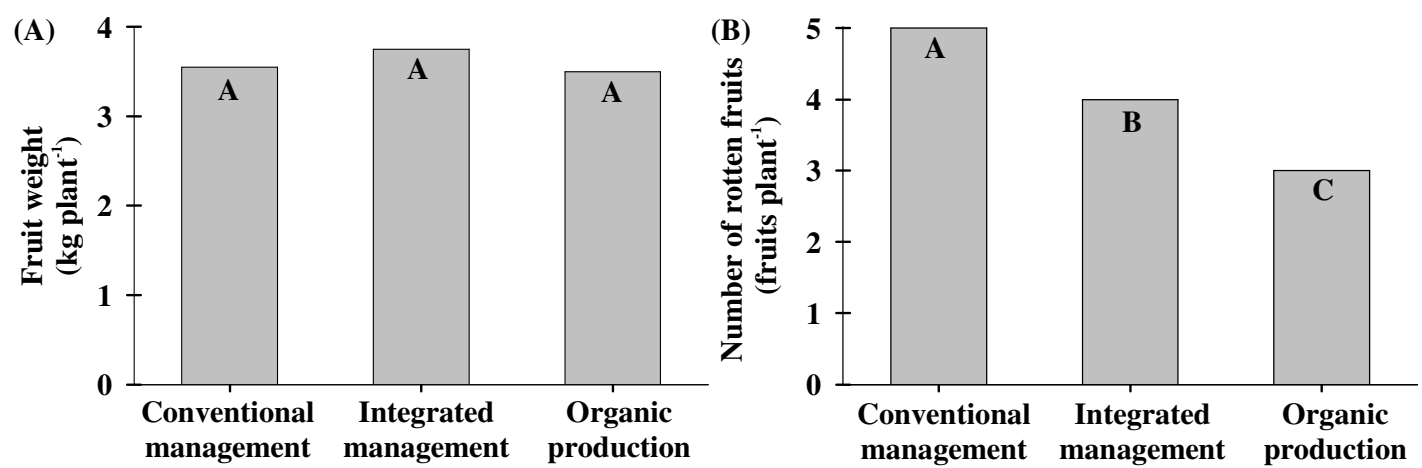

Figure 3. Fruit weight (A) and number of rotten fruits (B) in watermelon plants infected with gummy stem blight (Didymella bryoniae) and subjected to conventional management, integrated management and organic production from August to November 2012 (dry period). Different capital letters represent significant differences according to Tukey's test $(P<0.05)$.

The watermelon plants subjected to integrated management systems and organic production showed lower amount of rotten fruits compared to conventional management (Figure 3B). Although there had been differences in these treatments in the form of fertilization, in watermelon plants were planted with smaller spacing than conventional management (Table 1). The spacing of $2.0 \times 2.0 \mathrm{~m}$ is mostly used in planting of watermelon cultivars of American' origin and subjected to sprinkler irrigation (MIRANDA et al., 2005). Feltrim et al. (2011) noted that watermelon plants of the hybrid 'Top Gun' when planted in low-density
$(2.0 \times 2.0 \mathrm{~m})$ showed $125 \%$ increase in fruit production.

Higher yields were recorded when watermelon plants were grown in the conventional management system (Figure 4A), and larger amounts of rotten fruits in the other treatments were registered. Compared with the conventional management system, there was a decrease in productivity of $25 \%$ and $22 \%$ in the integrated management and the organic production systems, respectively. The variability in the productivity of a particular crop in the field may be inherent in the soil, climate, or even induced by the type of management (MIRANDA et al., 2005; LEÃO et al., 
2008). The difficulty in applying cultural practices contributes to the onset of diseases that cause defoliation of plants and result in low fruits yield (SOUZA et al., 2008; SANTOS et al., 2013); therefore, it is likely that the type of management was the key factor in the reduced productivity observed.
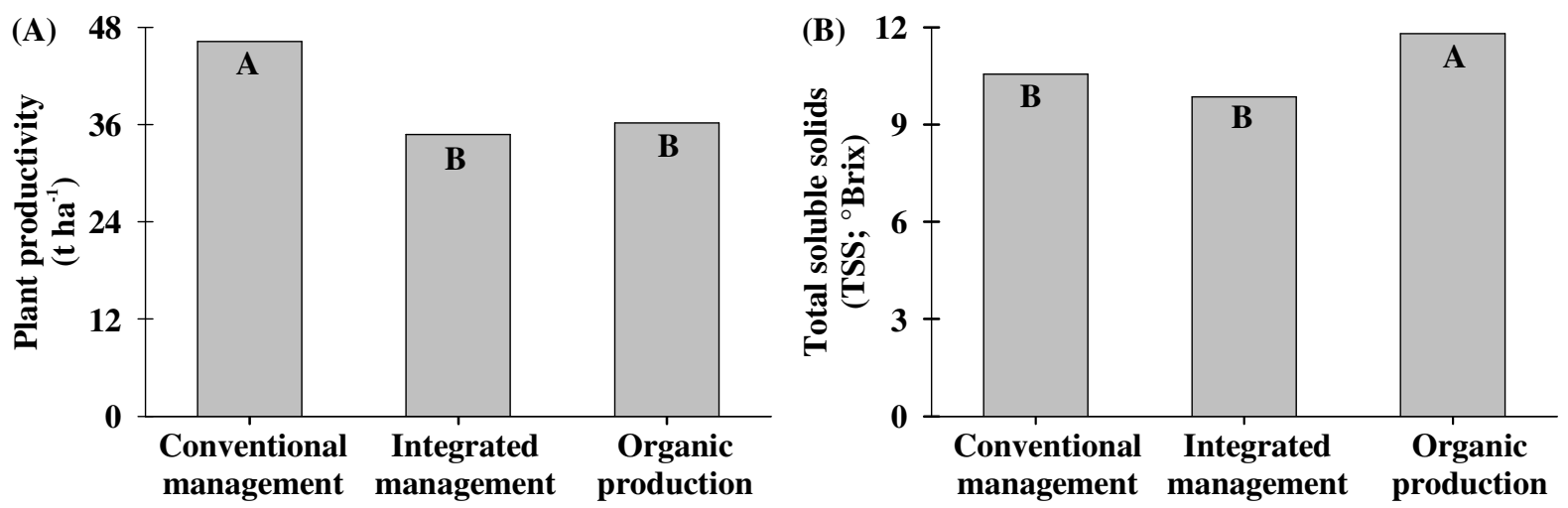

Figure 4. Plant productivity (A) and total soluble solids (B) of the watermelon infected with gummy stem blight (Didymella bryoniae) and submitted to conventional management, integrated management and organic production from August to November 2012 (dry period). Different capital letters represent significant differences according to Tukey's test $(P<0.05)$.

Plants subjected to organic management showed fruit with higher ${ }^{\circ}$ Brix compared to the other treatments (Figure 4B). The ${ }^{\circ}$ Brix of different cultivars of watermelon varies from nine to $12{ }^{\circ}$ Brix, and recorded values above $8{ }^{\circ}$ Brix in fruits of watermelon without stored seeds (FELTRIM et al., 2011). The fruits of watermelon subjected to organic management showed $11.8^{\circ}$ Brix. Despite not being recorded significant difference in AUDPC of plants subjected to organic management compared to conventional management, it is more advantageous to farm plants organically considering the higher ${ }^{\circ}$ Brix recorded in the pulp of theses fruits.
In this study, watermelon plants were studied to evaluate the efficiency of different production systems in the control of gummy stem blight in order to establish effective methods to combat the disease. After the application of treatments, conventional, integrated and organic production management, the severity of gummy stem blight and fruit quality were evaluated. Results showed that the management based on judicious monitoring in field is the best way to attain appropriate phytosanitary quality for growing watermelon crops in Tocantins State, Brazil.

RESUMO: A podridão gomosa (Didymella bryoniae) é uma doença que afeta a produtividade da melancia levando a perdas superiores a $40 \%$. Objetivou-se avaliar a eficiência de diferentes sistemas de produção no controle da podridão gomosa em melancia visando estabelecer métodos eficientes de combate à doença. Aplicou-se os seguintes tratamentos: manejo convencional, manejo integrado e cultivo orgânico. A adubação mineral foi aplicada em manejo convencional e no manejo integrado, enquanto que no cultivo orgânico foi utilizado o esterco bovino. Houve aplicação de fungicidas e inseticidas em doses comerciais no manejo convencional e manejo integrado, sendo que no manejo integrado a aplicação foi conforme monitoramento. A severidade da doença foi avaliada por escala de notas. O delineamento experimental foi blocos ao acaso. A severidade da podridão gomosa aumentou substancialmente na fase de formação dos frutos. Plantas de melancia cultivadas com o manejo integrado apresentaram menores níveis de severidade da doença, enquanto as plantas em cultivo orgânico exibiram maiores níveis de severidade. Conclui-se que o manejo baseado em acompanhamentos criteriosos em campo representa a melhor maneira de atingir o aspecto fitossanitário adequado para o cultivo de melancia no Estado do Tocantins, Brasil.

PALAVRAS-CHAVE: Didymella bryoniae. Adubação orgânica. Citrullus lanatus. Produtividade. 


\section{REFERENCES}

CAFÉ-FILHO, A. C.; SANTOS, G. R.; LARANJEIRA, F. F. Temporal and spatial dynamics of watermelon gummy stem blight epidemics. European Journal of Plant Pathology, Paris, v. 128, p. 473-482, 2010. http://dx.doi.org/10.1007/s10658-010-9674-1

EMBRAPA. Centro Nacional de Pesquisa de Solos. Sistema Brasileiro de Classificação de Solos. 2 ed. Rio de Janeiro: EMBRAPA Solos, 2006.

FELTRIM, A. L.; CECÍlIO FILHO, A. B.; GONSALVES, M. V.; PAVANI, L. C.; BARBOSA, J. C.; CORTEZ, J. W. M. Distancia entre plantas y dosis de nitrógeno y potasio en sandía sin semillas fertirrigada. Pesquisa Agropecuária Brasileira, Brasília, v. 46, n. 9, p. 985-991, 2011. http://dx.doi.org/10.1590/S0100204X2011000900003

IAL (Instituto Adolfo Lutz). Normas analíticas do Instituto Adolfo Lutz. Métodos químicos e físicos para análise de alimentos. São Paulo, 2008. 3. ed. v. 2.

IBGE (Instituto Brasileiro de Geografia e estatística). Lavouras temporárias 2013. Disponível em: <www.ibge.gov.br/estadosat/temas.php?sigla=to\&tema=lavouratemporaria2013>. Acesso em: 23 jun. 2015.

Kurozawa, C.; Pavan, M. A.; Rezende, J. A. M. Doenças das cucurbitáceas.In:Kimati, H.; Amorim, L.; Rezende, J.A.M.; Bergamin Filho, A.; Camargo , L. E. A. Manual de Fitopatologia: Doenças das Plantas Cultivadas. $4^{\mathrm{a} E d}$. São Paulo: Agronômica Ceres, v. 2, 293-310, 2005.

LEÃO, D. S. S.; PEIXOTO, J. R.; VIEIRA, J. V.; CECÍLIO FILHO, A. B. Produtividade de melancia em diferentes níveis de adubação química e orgânica. Bioscience Journal, Brasília, v. 24, n. 4, p. 32-41, 2008.

MIRANDA, F. R.; MONTENEGRO, A. A. T.; OLIVEIRA, J. J. G. Produtividade da melancia irrigada por gotejamento em diferentes espaçamentos de plantio. Revista Ciência Agronômica, Fortaleza, v. 36, n. 2, p. $158-162,2005$.

MORAIS, N. B.; BEZERRA, F. M. L.; MEDEIROS, J. F.; CHAVES, S. W. P. Resposta de plantas de melancia cultivadas sob diferentes níveis de água e de nitrogênio. Revista Ciência Agronômica, Fortaleza, v. 39, n. 3, p. 369-377, 2008.

SANTOS, G. R.; CAFÉ-FILHO, A. C. Reação de genótipos de melancia ao crestamento gomoso do caule. Horticultura Brasileira, Brasília, v. 23, p. 945-950, 2005. http://dx.doi.org/10.1590/S010205362005000400017

SANTOS, G. R., CAFÉ-FILHO, A. C.; SABOYA, L. M. F. Controle químico do crestamento gomoso do caule na cultura da melancia. Fitopatologia Brasileira, Brasília, v. 30, p. 155-163, 2005.

http://dx.doi.org/10.1590/S0100-41582005000200009

SANTOS, G. R.; CAFÉ-FILHO, A. C.; LEÃO, F. F.; CESAR, M.; FERNANDES, L. E. Progresso do crestamento gomoso e perdas na cultura da melancia. Horticultura Brasileira, Brasília, v. 23, p. 230-234, 2005. http://dx.doi.org/10.1590/S0102-05362005000200013

SANTOS, G. R.; FERREIRA, M. S. V.; PESSOA-FILHO, M. A. C. P.; FERREIRA, M. E.; CAFÉ-FILHO, A. C. Host specificity and genetic diversity of Didymella bryoniae from Cucurbitaceae in Brazil. Journal of Phytopathology, Londres, v. 157, p. 265-273, 2009. http://dx.doi.org/10.1111/j.1439-0434.2008.01475.x

SANTOS, G. R.; LEÃO, E. U.; GONÇALVES, C. G.; CARDON, C. H. Manejo da adubação potássica e da irrigação no progresso de doenças fúngicas e produtividade da melancia. Horticultura Brasileira, Brasília, v. 31, p. 36-44, 2013. http://dx.doi.org/10.1590/S0102-05362013000100006 
SHANER, G.; FINNEY, R. E. The effect of nitrogen fertilization on the expression of slow-mildewing resistance in Knox wheat. Phytopathology, Londres, v. 67, p. 1051-1056, 1977.

http://dx.doi.org/10.1094/Phyto-67-1051

SIMKO, I.; PIEPHO, H. P. The area under the disease progress stairs: Calculation, advantage, and application. Phytopathology, Londres, v. 102, p. 381-389, 2012. http://dx.doi.org/10.1094/PHYTO-07-11-0216

SOUZA, J. O.; MEDEIROS, J. F.; SILVA, M. C. C.; ALMEIDA, A. H. B. Adubação orgânica, manejo de irrigação e fertilização na produção de melão amarelo. Horticultura Brasileira, Brasília, v. 26, n. 1, p. 15-18, 2008. http://dx.doi.org/10.1590/S0102-05362008000100003

UCHÔA, C. N.; POZZA, E. A.; ALBUQUERQUE, K. S.; MORAES, W. S. Relação entre a temperatura e o molhamento foliar no monociclo da Sigatoka-negra. Summa Phytopathologica, Botucatu, v. 38, n. 2, p. 144$147,2012$.

WALTERS, S. A. Influence of plant density and cultivar on mini triploid watermelon yield and fruit quality. HortTechnology, Espanha, v. 19, p. 553-557, 2009. 